\title{
Formation of the Porous Structure of Cigarette Filters*
}

\author{
by François Coq and S. Vidal \\ Research Department, Société JOB, Perpignan, France
}

A porous structure, suitable for the filtration of tobacco smoke, is formed from filter material in band, or fibrous or filament form:

The experimental data used for the present study have been obtained by manufacturing filters from material in band form. However, the method and conclusions of the study can be applied to porous structures formed from material in fibrous or filament form and can even be generalised to cover other porous interstitial structures. It was verified experimentally that they apply to the porous structure of cigarettes formed from tobacco strands.

The standard porometric methods which allow the study of the spectrum of the structure pores and the measuring of the specific surface area of the material, are known. These methods are absolutely necessary for the knowledge of porous structures. However, a new contribution to this knowledge is described in this paper, using a different method based on permeametry.

Before describing the principle of this method, we shall discuss the process operations in the manufacture of filters by which the three-dimensional structure of the filter is formed.

\section{FORMATION PROCESS}

\section{OF THE POROUS STRUCTURE OF A FILTER}

The process as applied to filter material in band form will be described.

In a preliminary stage of the process the band is shaped into a plug. The band can be folded over in such a way that the material is arranged at random.

The formation of the plug can also be carried out in such a way that the material is arranged geometrically. Thus, the band can be cut into narrow strips, the strips piled one on top of the other and the pile then shaped in such a way that each strip takes on the form of a spiral " $\mathrm{S}$ " in order to obtain a homogenous combination in a cylindrical volume.

In both cases, the material elements form a porous interstitial structure which is a rough outline of the porous structure of the filter.

In the second stage of the process, the plug of material

\footnotetext{
" Reprinted from "Les Anasles du Tabac" 11-1973/1, pp. 93-104.

Presented at the CORESTA/26th TCRC Joint Conference held in willizmsburg, Virginiz, USA, is 1972.
}

is shaped cylindrically to a pre-determined diameter so as to produce the filter rod which is to be. wrapped in the wrapping paper.

This operation completes the formation of the porous structure of the filter by pressing together the material elements in juxtaposition and by assembling them by imbrication.

The process is essentially characterised by the fact that the filter material elements in juxtaposition, more or less pressed together and imbricated, are not crushed and preserve their relief and proper structure.

The amount of a given filter material used in the manufacture of a filter of a given volume cannot, therefore, exceed a certain limit, a limit which is determined by the resistance of the material to crushing.

Moreover, there exists a lower limit to the amount of material necessary to form the porous structure of a filter of a given volume. This is the limit corresponding to the onset of the laminar flow system of the smoke in the filter.

Both these limits determine, for each filter material, the range of filter densities for the manufacture of a filter.

(The expression "filter density" applies to the apparent density of the filter material in the filter.)

Both these limits depend on the properties of the material and on its arrangement in the filter. In most cases, they are roughly in the ratio of two to three.

\section{PERMEAMETRIC METHOD USED}

Porous structures of filters of the same dimensions, manufactured by the same process from the same filter material, differing from each other in the quantities of material used in their manufacture, i. e. in their densities, are taken into account. Thus all these porous structures are of the same type.

In all cases, the filter density being the independent variable, the porometric characteristics of the structure as well as the permeability are variables dependent on the density.

The principle of a method for examining a type of structure lies in the fact that the relationship existing between the density and a structural, porometric or permeametric characteristic, is specific to the type of structure. 
The permeametric method is that which is based on the existing relationship between the density and the permeability of structures of the same type.

Therefore, the permeability $(Q)$ of filters having the same dimensions, the same composition, manufactured in the same way, but differing in their densities (D) is measured and, according to the experimental values of $Q$ and $D$, the equation for a mathematical model of the relationship between $Q$ and $D$ is calculated.

The mathematical form of the model and the parametric constants appearing in the equation of this model will be the two basic data of the study.

If the mathematical model is of the same form, irrespective of the kind of filter material, it can be concluded that this mathematical form relates exclusively to the structural formation process.

In this case, if the constant parameters appearing in the equation of the model differ from one filter material to another, the structural properties of the filter material used can be characterised by these parameters.

\section{Nomenclature of Symbols}

\section{D : Apparent filter density.}

N.B. The filter volume always being constant and equal to $0.905 \mathrm{~cm}^{3}, \mathrm{D}$ is, in all cases, linked to the weight by the relationship $D=\frac{P}{0.905}$, $P$ being the weight of the filter in grams.

$Q$ : Filter air permeability (air flow passing through the filter in ml per second under a constant pressure of $50 \mathrm{~mm}$ of water).

$D_{0}$ : Filter density at the filling limit by compression.

$\frac{1}{D_{0}}:$ Specific volume of the compressed material.

$Q_{0}$ : Filter permeability at the filling limit by compression.

$\varphi$ : Coefficient of interstitial permeability. The dimensions of $\varphi$ are those for permeability.

\section{EXPERIMENTAL CONDITIONS}

For a given material, the cigarette filters were manufactured so as to be of a fixed size (diameter and length) with different density levels $D$, either by machine or, as in most cases, by hand.

In the case of filters made by hand, the laboratory device used for the formation of the bands of material into filter rods reproduced the same operating conditions as the plug machine. In all cases the measurements were taken after the filter tips of $8 \times 18 \mathrm{~mm}$ had been cut from the rods.

For each density level $D$, the air permeability $Q$ of 25 filters was measured using a $V_{A}$ type standard suction porosimeter of the Stockholm collective experiment (see Figure I).

\section{Figure 1. Scheme of porosimeter used tor measuring} permeability.

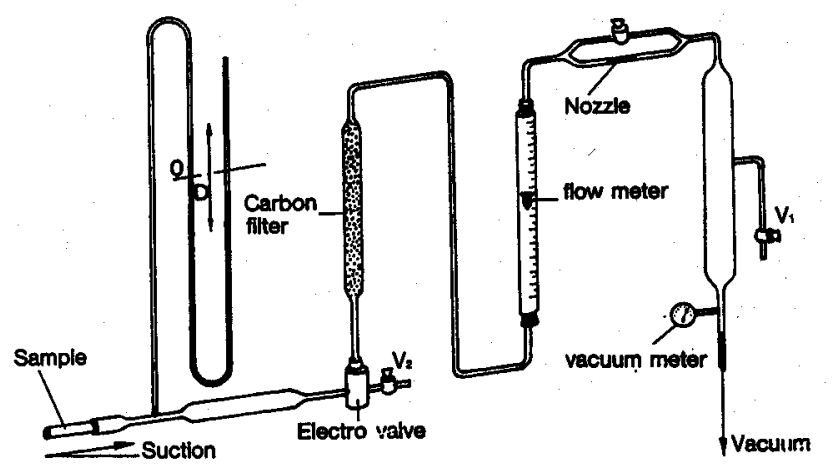

The densities $D$ were spread over the range of filter densities corresponding to the standard limits: of manufacture of the filters. This range is limited by two densities:

1. The lowest density where the filter structure is already formed and which corresponds, as the experiment shows, to the onset of the laminar flow system.

2. The highest feasible density from a practical point of view by the standard means of manufacture.

Table 1. Characteristlcs of the different Initial materials.

\begin{tabular}{|c|c|c|c|c|c|c|c|}
\hline & \multicolumn{2}{|c|}{$\begin{array}{c}\text { Substance } \\
\text { (g) }\end{array}$} & \multicolumn{2}{|c|}{$\begin{array}{l}\text { Thickness } \\
\text { (mm) }\end{array}$} & \multirow{2}{*}{$\begin{array}{c}\text { Crimping rate: } \\
\text { Crimped substance/ } \\
\text { non-crimped } \\
\text { substance }\end{array}$} & \multicolumn{2}{|c|}{$\begin{array}{l}\text { Specific volume or bulk } \\
\qquad\left(\mathrm{cm}^{3} / \mathrm{g}\right)\end{array}$} \\
\hline & Crimped & $\begin{array}{c}\text { Non- } \\
\text { crimped }\end{array}$ & Crimped & $\begin{array}{c}\text { Non- } \\
\text { crimped }\end{array}$ & & Real & Apparent \\
\hline Cellulose wadding No. 1 & 24 & 15 & 0.32 & 0.060 & 1.70 & 4 & 13.3 \\
\hline Cellulose wadding No. 2 & 21 & 13 & 0.25 & 0.065 & 1.60 & 5 & 12 \\
\hline Standard crimped paper & 55 & 17 & 0.40 & 0.040 & 3.30 & 2.3 & 7.2 \\
\hline Tissue: 2 -fold & $2 \times 15.5$ & $2 \times 13$ & $\begin{array}{c}0.07 \\
(1-\text { fold })\end{array}$ & $\begin{array}{c}0.045 \\
(1-\text { fold })\end{array}$ & 1.20 & 3.6 & 4.5 \\
\hline Tissue: 1-fold & 22 & 18.5 & 0.09 & 0.060 & 1.20 & 3.2 & 4.1 \\
\hline Fluted paper (40 g) & - & 40 & - & 0.070 & 0 & 1.7 & 一 \\
\hline Longitudinally crimped paper & $r \quad-$ & 45 & 0.48 & 一 & - & - & 10.6 \\
\hline
\end{tabular}




\section{EXPERIMENTAL RESULTS}

A large number of filter series were made in this way using the different types of material (singly or combined) commonly used in the paper cigarette filter industry, such as:

- standard crimped paper

- longitudinally crimped paper

- finely grooved fluted paper

- cellulose wadding and "tissue"

Tobacco strands were also tested.

The characteristics of the different materials mentioned above are shown in Table 1.

In all cases, the experimental values of $Q$ and $D$ obtained for each type of material were plotted statistically by the polynomial method, using a computer.

In all cases, this led to the mathematical model:

$$
Q=\alpha D^{2}-\beta D+\gamma
$$

N.B. In the polynomial regression method, precision depends on the value of standard error of estimate, quotient of the square root of the sum of residual deviations by the number of degrees of freedom minus one.

For each of the twenty-nine groups of points, the standard error of estimate is low allowing acceptance of the proposed mathematical model within a satisfactory limit of confidence.

$$
\begin{aligned}
& \text { Average standard error : } \\
& \text { Range }
\end{aligned}\left\{\begin{array}{l}
0.32703 \\
0.07344 \\
0.99686
\end{array}\right.
$$

A defined model interpreting the modification of the porous filter structure by the filling must correspond to the mathematical model (equation No. 1) expressing the relationship between $D$ and $Q$.

\section{FILLING THE FILTER BY COMPRESSION OF FILTER MATERIAL}

Equation No. 1 can be written in the following way:

$$
\mathrm{Q}=\mathrm{Q}_{0}+\left(1-\frac{\mathrm{D}}{\mathrm{D}_{0}}\right)^{2} \text {. }
$$

The group of graphs of Figure 2 represents all the parabolas calculated using equation No. 2 corresponding to the different materials or combinations of materials studied.

According to the mathematical model expressed by the equation No. 2, the density of a filter of a given composition cannot exceed density $D_{0}$.

A filter having a density $D_{0}$ is at the upper limit of the filling range, i.e. it is $1.00 \%$ filled.

At this density $D_{0}$, the material is imbricated and assembled by compression while still maintaining its proper structure and relief. The specific volume of the material assembled in such a way is equal to $\frac{I}{D_{0}}$.

A filter having a density $D$ lower than $D_{0}$ has a filling rate equal to $\frac{D}{D_{0}}$. The filling rate can vary down to the lower limit of the filling range. At this limit it is about $60 \%$ to $70 \%$, according to the filter material used.

Figure 2. Group of experimental parabolas calculated using equation 2: $Q=Q_{0}+\left(1-\frac{D}{D_{0}}\right)^{2}$.

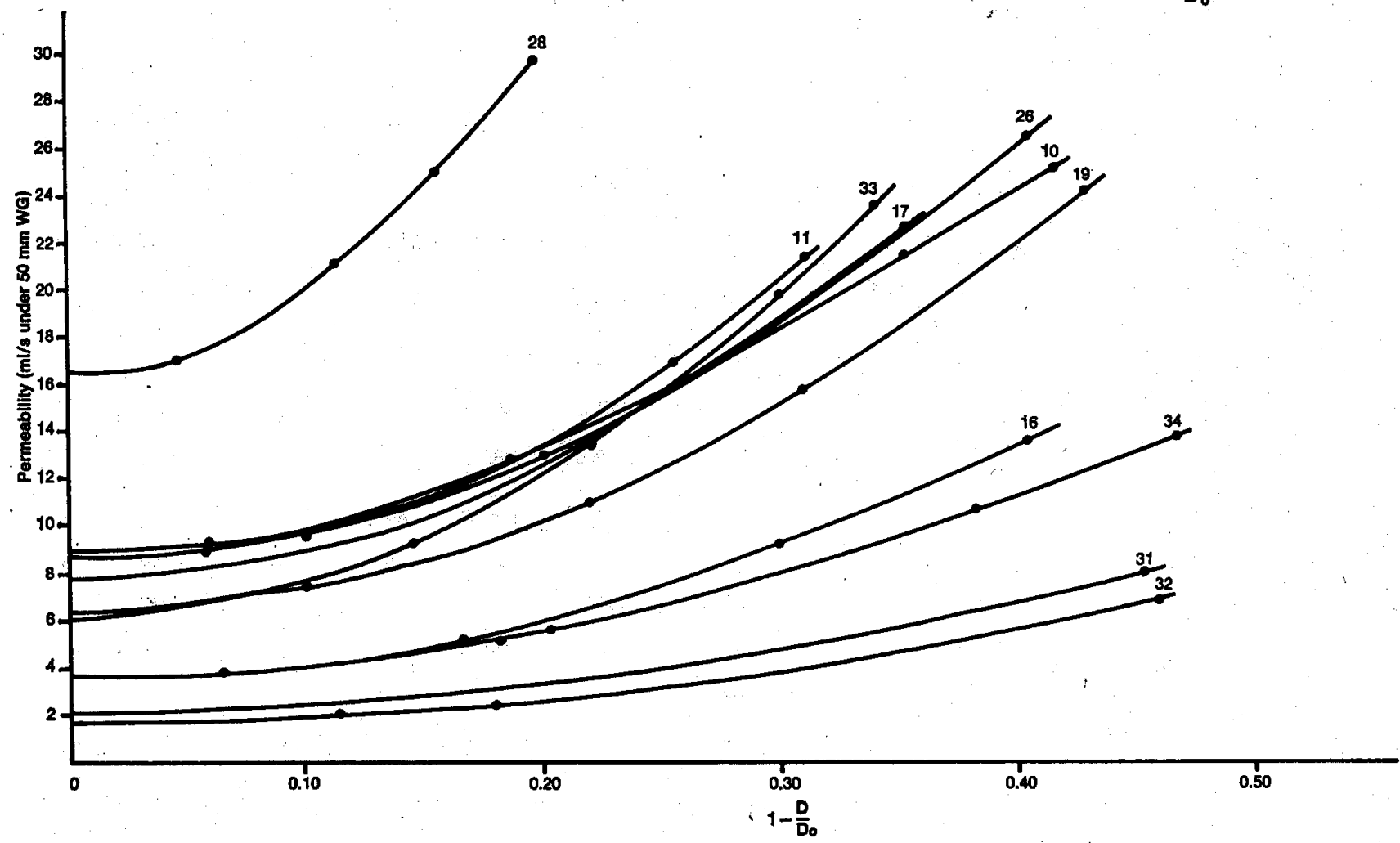


In a filter having a density $D$, there remains a filling margin equal to $1-\frac{D}{D_{0}}$.

Variable Change in the Mathematical Model Equation The filling margin $\left(1-\frac{D}{D_{0}}\right)$ will be the variable on which the permeability variation depends.

If $V=I-\frac{D}{D_{0}}$, the equation No. 2 can be written in the following way:

$$
\mathrm{Q}=\mathrm{Q}_{0}+\varphi \mathrm{V}^{2}
$$

The unit of volume being the filter volume, variable $\mathrm{V}$ represents the volume of material having a density $D_{0}$ which could be inserted by compression into a filter having a density $D$.

\section{Formation of the Porous Structure by a Compression Process}

According to equation No. 3, the permeability of a filter of a given type is the sum of two terms: a constant term $Q_{0}$ and a term which depends on the filling margin $\varphi \mathrm{V}^{\mathbf{2}}$.

It can be deduced from this mathematical form of the model that the porous network is not wholly modified by a change in filling. This means that the pores belonging to the filter material elements, internal pores, some of the grooves and some of the relief cavities, are not modified by the change in filling.

Thus it can be verified that the structural formation takes place by a filling process without crushing the filter material.

\section{Significance of the Parabolic Form of the Model}

It has been said that the filling variable $V$, or filling margin, is the volume of material having a density $D_{0}$ that could be introduced by compression into a filter having a density $D$. It is an unfilled interstitial volume or, more precisely, the margin of possibility of imbrication or of assembly of the material elements.

According to equation No. 3 , the permeability of a filter having a density $D$ is equal to the permeability of a hundred per cent filled filter $\left(Q_{0}\right)$ increased by a supplement which is a variable dependent on the unfilled interstitial space (V). This supplement represents the difference existing between the permeability of the unfilled interstitial void and the permeability of the same space when filled.

The mathematical model can also be expressed by the equation No. 3 in its differential form:

$$
\mathrm{dQ}=\varphi \mathrm{VdV} \quad \text {. }
$$

\begin{tabular}{|c|c|c|c|c|c|}
\hline Materials & $\begin{array}{c}\text { Parabola } \\
\text { No. }\end{array}$ & $\alpha D^{2}-\beta D+\gamma$ & Do & Qo & $\boldsymbol{\varphi}$ \\
\hline $\begin{array}{l}\text { Tissue (1-fold) }{ }^{*}: 19 \mathrm{~g} / \mathrm{m}^{2}-h=370 \mu \\
\text { Cellulose wadding: } 24 \mathrm{~g} / \mathrm{m}^{2}-h=450 \mu\end{array}$ & 10 & $2267 D^{2}-998 D+119$ & 0.220 & 9.16 & 109.7 \\
\hline $\begin{array}{l}\text { Tissue (1-fold) }{ }^{*}: 19 \mathrm{~g} / \mathrm{m}^{2}-\mathrm{h}=370 \mu \\
\text { Cellulose wadding: } 21 \mathrm{~g} / \mathrm{m}^{2}-\mathrm{h}=360 \mu\end{array}$ & 11 & $2450 D^{2}-1103 D+133$ & 0.225 & 8.90 & 124 \\
\hline $\begin{array}{l}\text { Tissue (1-fold) }{ }^{*}: 20.2 \mathrm{~g} / \mathrm{m}^{2}-h=370 \mu \\
\text { Cellulose wadding: } 21.6 \mathrm{~g} / \mathrm{m}^{2}-\mathrm{h}=450 \mu\end{array}$ & 12 & $1017 D^{2}-506 D+68$ & 0.249 & 5.06 & 63 \\
\hline "Caporal" tobacco (fine-cut) & 16 & $224 D^{2}-216 D+56$ & 0.480 & 3.90 & 52 \\
\hline $\begin{array}{l}\text { Tissue (1-fold)*: } 19 \mathrm{~g} / \mathrm{m}^{2}-\mathrm{h}=410 \mu \\
\text { Cellulose wadding: } 21 \mathrm{~g} / \mathrm{m}^{2}-\mathrm{h}=360 \mu\end{array}$ & 17 & $2606 D^{2}-1135 D+131$ & 0.217 & 7.66 & 123 \\
\hline $\begin{array}{l}\text { Tissue (1-fold) }{ }^{*}: 19 \mathrm{~g} / \mathrm{m}^{2}-\mathrm{h}=320 \mu \\
\text { Cellulose wadding: } 21 \mathrm{~g} / \mathrm{m}^{2}-\mathrm{h}=360 \mu\end{array}$ & 19 & $1977 D^{2}-865 D+101$ & 0.219 & 6.38 & 95 \\
\hline $\begin{array}{l}40 \% \text { Minl-crimped paper*: } 27 \mathrm{~g} / \mathrm{m}^{2}-\mathrm{h}=360 / 380 \mu \\
60 \% \text { Cellulose wadding: } 21 \mathrm{~g} / \mathrm{m}^{2}-\mathrm{h}=360 \mu\end{array}$ & 20 & $1342 D^{2}-736 D+108$ & 0.274 & 7.30 & 98.7 \\
\hline $\begin{array}{l}\text { Tissue (2-fold)": } 29.5 \mathrm{~g} / \mathrm{m}^{2}-\mathrm{h}=430 \mu \\
\text { Cellulose wadding: } 21 \mathrm{~g} / \mathrm{m}^{2}-\mathrm{h}=360 \mu\end{array}$ & 26 & $1914 D^{2}-914 D+118$ & 0.239 & 8.84 & 109 \\
\hline $100 \%$ Standard crimped paper: $55 \mathrm{~g} / \mathrm{m}^{2}$ & 28 & $1629 D^{2}-1467 D+347$ & 0.450 & 16.7 & 330 \\
\hline $\begin{array}{l}100 \% \text { Cellulose wadding : } 31 \mathrm{~g} / \mathrm{m}^{2}-\mathrm{h}=360 \mu \\
\text { Tissue (2-fold) }\end{array}$ & 29 & $2237 D^{2}-983 D+116$ & 0.219 & 8.09 & 107 \\
\hline $\begin{array}{l}100 \% \text { Cellulose wadding*: } 31 \mathrm{~g} / \mathrm{m}^{2}-\mathrm{h}=300 \mu \\
\text { Tissue (2-fold) }\end{array}$ & 30 & $1355 D^{2}-674 D+89.6$ & 0.249 & 5.86 & 84 \\
\hline $100 \%$ Cellulose wadding No. 1 & 31 & $567 D^{2}-287 D+389$ & 0.253 & 2.68 & 36 \\
\hline $100 \%$ Cellulose wadding No. 2 & 32 & $634 D^{2}-247 D+265$ & 0.195 & 1.90 & 24 \\
\hline $\begin{array}{l}\text { F.60: } 40 \% \text { Standard crimped paper } \\
60 \% \text { Cellulose wadding: } 21 \mathrm{~g} / \mathrm{m}^{2}\end{array}$ & 33 & $1588 D^{2}-843 D+118$ & 0.265 & 6.08 & 111 \\
\hline Longitudinally crimped paper & 34 & $590 D^{2}-279 D+43$ & 0.280 & 3.8 & 39 \\
\hline $\begin{aligned} \text { Group A: } 50 \% \text { Fluted paper }\left(40 \mathrm{~g} / \mathrm{m}^{2}\right)^{*} \\
50 \% \text { Cellulose wadding }\left(21 \mathrm{~g} / \mathrm{m}^{2}\right)\end{aligned}$ & 35 & $1583 D^{2}-766 D+103$ & 0.310 & 13 & 152 \\
\hline
\end{tabular}

Table 2. Values of $D_{0}, Q_{0}$ and $\varphi$ for the different materials used.

\footnotetext{
- After being embossed in longitudinally fine grooves.
} 
According to this differential equation, the filling of an infinitesimal volume $d V$ causes the permeability to vary proportionately to the filling margin (V).

The parabolic form of this model can be compared to the laminar flow laws of a gas in a porous structure.

\section{COEFFICIENT OF INTERSTITIAL PERMEABILITY $\varphi$}

In Table No. 2, the calculated values of $D_{0}, Q_{0}$ and $\varphi$ are assembled for each of the materials or combinations of materials used, as well as all the equations written in the following form:

$$
Q=\alpha D^{2}-\beta D+\gamma .
$$

The corresponding parabolas are shown in Figure 3.

In the case of the filters composed of bands of two different materials (single-fold sheet tissue + cellulose wadding) and geometrically conformed to an $S$ (graphs No. 11, 17, 19), the influence of the crimping height of the cellulose wadding and of the grooves of fluting was studied.

The coefficient $\varphi$ characterises, for each material, the modification in the porous structure by variation in filling. This modification of structure consists of a variation in different porometric factors which act simultaneously: average radius, number and dispersion of the size of the interstices, form and orientation of these interstices in relation to the main fluid flow.

Fgure 3. Group of experimental parabolas calculated using the following equation: $Q=\alpha D^{2}-\beta D+\gamma$.

Permeabillity ( $\mathrm{ml} / \mathrm{e}$ under $50 \mathrm{~mm}$ WQ)

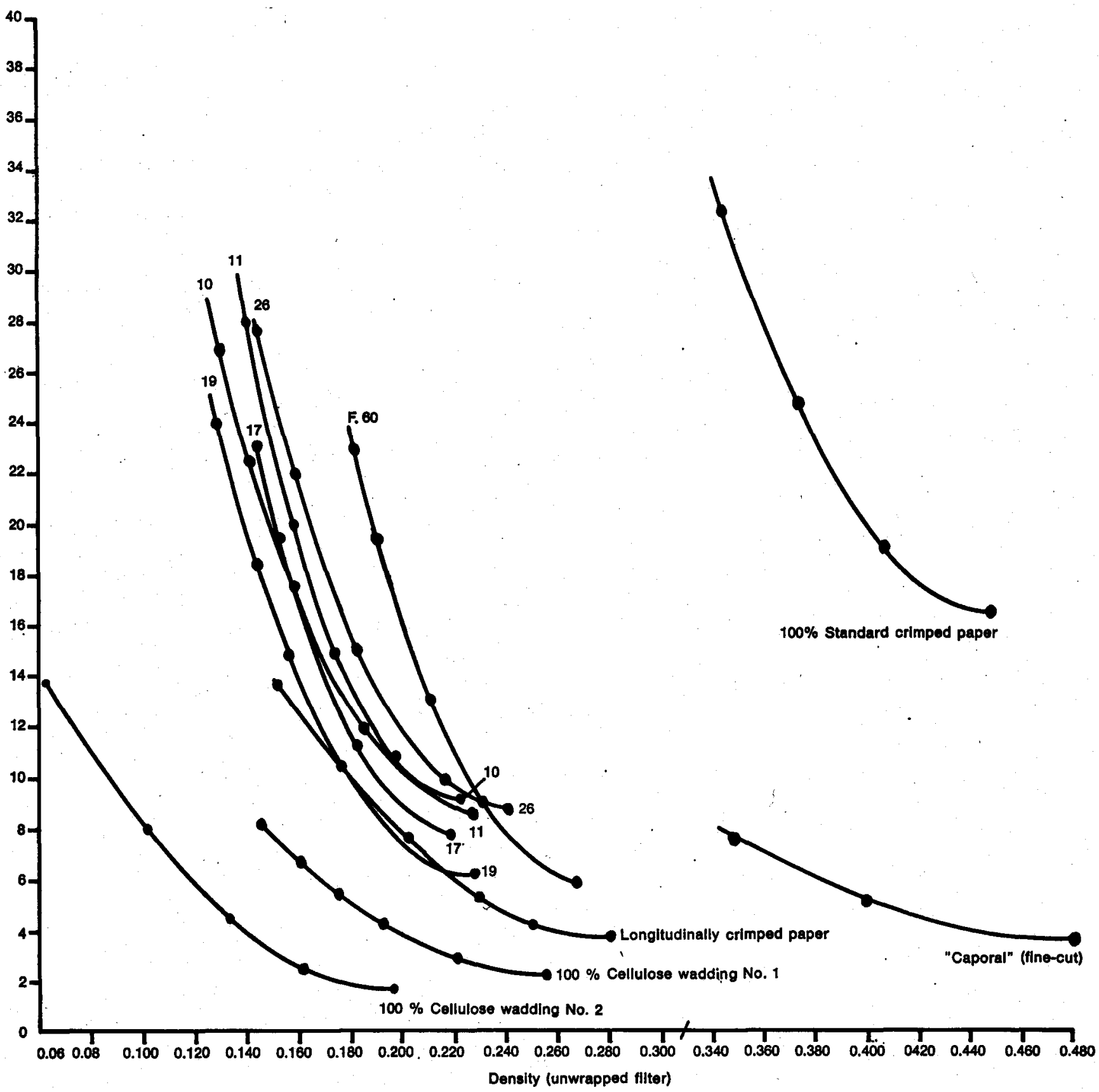


It is known that the filter structure is formed:

- on the one hand, of solid filter material elements practically uncompressible, of which the micro-voids are not significantly modified by variation in the filling pores within or on the surface of the material,

- and on the other hand, of the interstitial spaces separating the filter material elements, in juxtaposition and more or less compressed and imbricated according to the filling rate.

The unfilled fraction of the volume of the filter with a density $D,\left(I-\frac{D}{D_{0}}=V\right)$ is distributed in this network of interstitial spaces.

$\varphi$ indicates the extent of modification in the filter structure when filled, when the volume of the unfilled interstitial spaces decreases towards zero leaving only the porous network of the material corresponding to state $D_{0} . \varphi$ thus characterises the structural difference which exists between two filters of different filling rates.

It is established that $\varphi$ is high when there is a large difference between the loosely filled porous structure and the porous structure at state $D_{0}$. This is the case with materials of high density, with a rough and only slightly deformable relief, such as standard crimped paper. In this case, the value of $\varphi$ is of the order of 300 .

The values of $\varphi$ are low in the case of a slight difference between the porous structure only slightly filled and the porous structure of $D_{0}$. This is the case with absorbent, soft, light and fluffy, easily compressible cellulose wadding or "tissue". Their compressed crimping creates a porous network in the initial filter already made up of fine and numerous voids which do not change significantly during filling. In this case, the value of $\varphi$ is of the order of 30 .

Intermediate values of $\varphi$ correspond to combinations of these two types of material.

\section{CORRELATION BETWEEN $\varphi$ AND $Q_{0}$}

A close correlation is established (see Figure 4) between $\varphi$ and $Q_{0}$, and the following conclusion can be drawn from this combination.

The correlation coefficient value $\mathrm{k}=0.93$ is sufficiently high as to indicate that in reality $\varphi$ and $Q_{0}$ are functionally linked - the slight difference being explained by the imprecision of the permeability measures.

In fact, the equation of the linear graph as plotted (Figure 4)

$$
Q=17.47 Q_{0}-22.20
$$

was determined taking into account the isolated point No. 28 (100\% standard crimped). If this isolated point is disregarded, the correlation coefficient $(k)$ becomes 0.95 and the line passes through the origin.
Figure 4. Correlation between $\varphi$ and $Q_{0}$ (correlation coefficlent $=\mathbf{0 . 9 3}$ ).

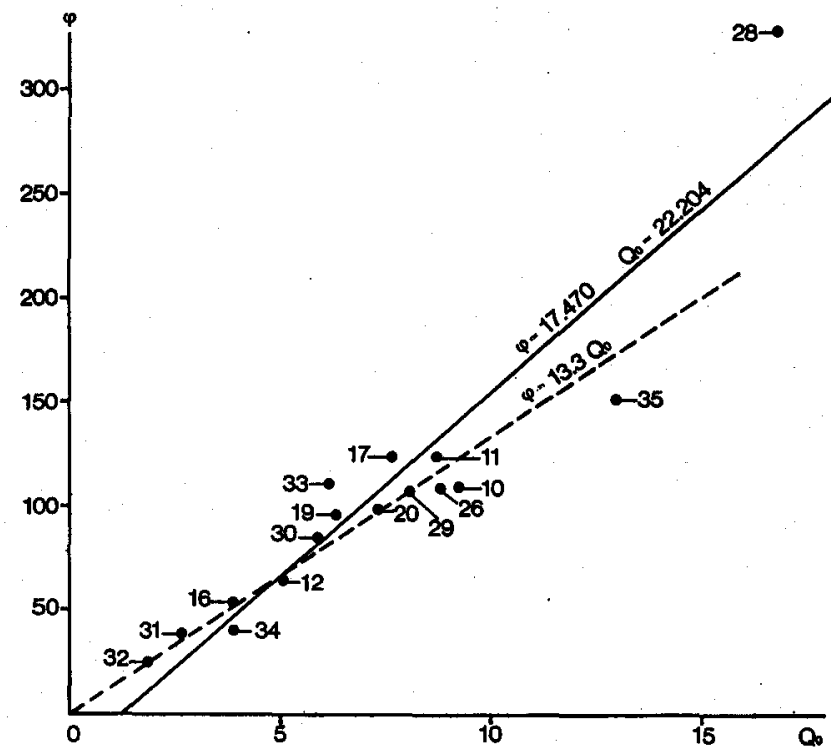

10: Tissue (1-fold): $19 \mathrm{~g} / \mathrm{m}^{2}-h=370 \mu+$ cellulose wadding: $24 \mathrm{~g} / \mathrm{m}^{2}$ $-h=450 \mu$.

11: Tissue (1-fold): $19 \mathrm{~g} / \mathrm{m}^{2}-\mathrm{h}=370 \mu+$ cellulose wadding: $21 \mathrm{~g} / \mathrm{m}^{2}$ $-h=360 \mu$.

12: Tissue (1-fold): $20 \mathrm{~g} / \mathrm{m}^{2}-\mathrm{h}=370 \mu+$ cellulose wadding: $21.6 \mathrm{~g} / \mathrm{m}^{2}$ $-h=450 \mu$.

16: "Caporal" tobacco (fine-cut).

17: Tissue (1-fold): $19 \mathrm{~g} / \mathrm{m}^{2}-\mathrm{h}=410 \mu+$ cellulose wadding: $21 \mathrm{~g} / \mathrm{m}^{2}$ $-h=360 \mu$.

19: Tissue (1-fold): $19 \mathrm{~g} / \mathrm{m}^{2}-\mathrm{h}=320 \mu+$ cellulose wadding: $21 \mathrm{~g} / \mathrm{m}^{2}$ $-\mathrm{h}=\mathbf{3 6 0} \mu$.

20: $40 \%$ Mini-crimped paper: $27 \mathrm{~g} / \mathrm{m}^{2}-\mathrm{h}=360 \mu+60 \%$ cellulose wadding: $21 \mathrm{~g} / \mathrm{m}^{2}-\mathrm{h}=360 \mu$.

26: Tissue (2-fold): $29,5 \mathrm{~g} / \mathrm{m}^{2}-\mathrm{h}=430 \mu+$ cellulose wadding: $21 \mathrm{~g} / \mathrm{m}^{2}$ $-h=360 u$.

28: Standard crimped paper: $55 \mathrm{~g} / \mathrm{m}^{2}$.

29: $100 \%$ Cellulose wadding (tissue, 2-fold): $31 \mathrm{~g} / \mathrm{m}^{2}-\mathrm{h}=300 \mu$.

30: $100 \%$ Cellulose wadding (lissue, 2-fold): $31 \mathrm{~g} / \mathrm{m}^{2}-h-300 \mu$.

31: $100 \%$ Cellulose wadding No. 1.

32: $100 \%$ Cellulose wadding No. 2.

33: F. 60: $40 \%$ Standard crimped paper $+60 \%$ cellulose wadding (21 $\left.\mathrm{g} / \mathrm{m}^{2}\right)$.

34: Longitudinally crimped paper.

35: Group A: $50 \%$ fluted paper $\left(40 \mathrm{~g} / \mathrm{m}^{2}\right)+50 \%$ cellulose wadding $\left(21 \mathrm{~g} / \mathrm{m}^{2}\right)$.

From this it is deduced that the variation in the filter density by filling modifies the porous structure of filters manufactured by using a given material, but preserves the character of this structure.

In other words, filters composed of the same material are of the same structural type irrespective of their density. This type of structure can be characterised by $\varphi$ or $Q_{0}$ since these two parameters are linked functionally.

\section{FIELD OF PRACTICAL APPLICATION}

The field of application of this study covers a wide area, from the research and from the industrial points of view.

Its practical interest is based on the particular characteristics of the porous structure at the filling limit by compression represented by the vertex of the parabolas of coordinates $D_{0}$ and $Q_{0}$. 
Figure 5. Practical application of the study for the choice of an efficlent filter material.

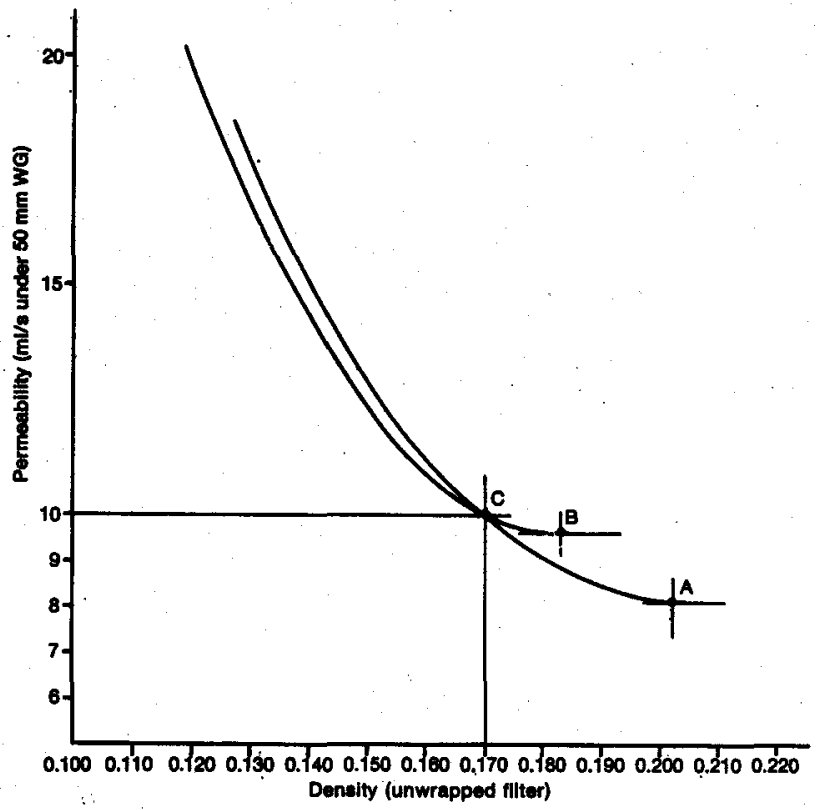

For the optimization of a filter the systematic plotting of the graph permeability-density leading by calculation to the knowledge of the specific parameters of the filter material, has considerable value both for research and for manufacturing control.

A frequent problem is to obtain a maximum retention and an optimum hardness for an average permeability imposed by the customer. A corollary problem is to minimise as much as possible the dispersion of these characteristics.

To reconcile the weight, pressure drop, hardness and retention requirements, knowledge of the structural characteristics of the material defined by the study helps the filter manufacturer to arrive at his choice.

To obtain the best structural regularity, the higher the value of $\varphi$ the closer it is necessary to approach the filling limit $D_{0}$. The filling rate $\frac{D}{D_{0}}$ near to $I$ assures the best filter compactness. Moreover, in the zone of the parabola with an almost horizontal tangent, there is minimum permeability variation with density differences due to variation of material substance.

\section{Example}

Figure 5 and Table 3 correspond to a typical example of practical application of the study for the choice of an efficient filter material.

The two parabolas A and B forming the intersection C were plotted from filters made from identical filter material (fluted paper + cellulose wadding) but with differences in the depth of the reliefs of the fluted and crimped material. The intersection point $C$ is situated near to the vertex of the parabola $B$ while it is rather far from the vertex of the parabola A. Cigarette filters of the two types were manufactured with a density $\mathrm{D}=0.170$, abscissa of point $\mathrm{C}$ and tar retention efficiency measures were taken. The percentage in
Table 3. Practical application of the study for the choice of an efficient filter material.

\begin{tabular}{lc|c|c}
\cline { 2 - 4 } & $\begin{array}{c}\text { Density } \\
\left(\mathrm{g} / \mathrm{cm}^{3}\right)\end{array}$ & $\begin{array}{c}\text { Permeability } \\
(\mathrm{ml} / \mathrm{s} / 50 \mathrm{~mm} \\
\text { WG })\end{array}$ & $\begin{array}{c}\text { Tar retention } \\
(\%)\end{array}$ \\
\hline Filter A & 0.170 & 10 & 43 \\
Filter B & 0.170 & 10 & 47 \\
\hline
\end{tabular}

retention gain was found to be equal to $9.3 \%$ in favour of filters belonging to group B.

\section{POSSIBILITY OF EXTENDING THE PERMEAMETRIC METHOD TO THE STUDY OF POROUS INTERSTITIAL STRUCTURES}

The permeametric method applied to the study of the porous structures of filters is valid for other porous structures formed by filling a cylindrical volume with material in sheet or strand form.

It is reasonable to think that all porous interstitial structures are modified when filled according to the process which has been studied for cigarette filters. That is why it was possible to apply it to cigarettes for the study of tobacco rod structure: The filling capacity of several different kinds of tobacco of the same origin but differing in their strand size, can be determined and compared by plotting the corresponding parabolas and by calculating the three characteristics $Q_{0}, D_{0}$, and $\varphi$. It has been shown that the value of the coefficient $\varphi$ varies with the width of the strands. More precisely, $\varphi$ increases in close relation to the width of strands (Table 4 ).

Table 4. Width of tobacco strands.

\begin{tabular}{l|c|c}
\hline Tobacco type & $\begin{array}{c}\text { Mean of } \\
10 \text { measure- } \\
\text { ments }\end{array}$ & $\varphi$ \\
\hline "Caporal" (fine-cut) & $0.25 \mathrm{~mm}$ & 52 \\
Superior "Scaferlati" & $0.50 \mathrm{~mm}$ & 68 \\
"Bergerac" & $0.70 \mathrm{~mm}$ & 81 \\
"St. Claude" & $1.00 \mathrm{~mm}$ & 97 \\
\hline
\end{tabular}

\section{SUMMARY}

An original method based on permeability measurement is applied to studying the formation of the porous interstitial structure of cigarette filters.

Using this method, it is shown that the porous structure of a filter is formed in the course of the filling process which is accomplished by compression of the filter material without significantly modifying the specific structure of this material. In the filling process, the elements of the filter material are assembled in the filter by imbrication.

A given filter material is characterised by the specific volume that it takes up when its elements are assembled at the compression limit without any crushing. A filter 
material is, moreover, characterised by the mode of assembling of its elements in the formation of the porous interstitial structure of a filter. The permeametric method allows us to define this characteristic

The results can be applied to the choice of filter material and to the determination of the optimum filling rate permitting the rapid development of a cigarette filter with fixed characteristics.

\section{ZUSAMMENFASSUNG}

Zur Untersudhung der Bildung der interstitiellen porösen Struktur von Cigarettenfiltern bedienen sich die Autoren einer auf dem Prinzip der Permeabilitätsmessung basierenden Originalmethode.

Mit Hilfe dieses Verfahrens wird gezeigt, daß die poröse Struktur eines Filters im Verlauf des Füllungsvorganges gebildet wird, bei dem das Filtermaterial ohne wesentliche Veränderung seiner spezifischen Struktur zusammengepreBt wird. Die Teile des Filtermaterials werden dabei im Filter schuppenartig angeordnet.

Ein gegebenes Filtermaterial ist durch das spezifische Volumen gekennzeichnet, das es einnimmt, wenn es ohne Zerquetschung seiner Teile bis zur Kompressionsgrenze zusammengedrückt wird. Darüber hinaus ist ein Filtermaterial durch die Art und Weise gekennzeichnet, in der seine Teile bei der Bildung der interstitiellen porösen Struktur des Filters zusammengefügt werden. Dieses Charakteristikum kann mit Hilfe der Permeabilitätsmessung definiert werden.

Die Ergebnisse können auf die Auswahl des Filtermaterials und die Bestimmung des optimalen Füllungs- grades angewendet werden und erlauben die schnelle Entwicklung eines Cigarettenfilters mit bestimmten Eigenschaften.

\section{RESUME}

On applique une méthode originale basée sur la perméamétrie pour étudier la formation de la structure poreuse intersticielle des filtres à cigarettes.

Par cette méthode, on démontre que la structure poreuse d'un filtre est formée par un remplissage du filtre opéré par tassement de la matière filtrante sans que la structure propre de cette matière soit significativement modifiée. Par ce processus de remplissage, les éléments de la matière filtrante sont assemblés dans le filtre par imbrication.

Une matière filtrante donnée est caractérisée par le volume spécifique qu'elle occupe quand ses éléments sont assemblés à lá limite de tassement sans écrasement. Une matière filtrante est, d'autre part, caractérisée par le mode d'assemblage de ses éléments dans la formation de la structure poreuse intersticielle $d$ 'un filtre. La méthode perméamétrique permet de définir cette caractéristique.

On en tire des applications pratiques concernant le choix de la matière filtrante et la détermination du taux de remplissage optimal permettant la mise au point rapide d'un filtre à cigarette de caractéristiques imposées.

The authors' address:

Société JOB, Research Department, 15 rue Emile-Zola, B.P. 424, F-66004 Perpignan, France. 